\title{
The Analysis of China’s Log Import and International Illegal Logging
}

\author{
Huwen Zhang, Kuanqi Du*
}

School of Economics and Management, Nanjing University of Science and Technology Nanjing, China

*Corresponding author: Kuanqi Du, 783680402@qq.com

\begin{abstract}
Using country-specific data from 1996 to 2015, this paper analyses the import demand of China's log with parameter estimates model and price elasticity estimates model. The empirical analysis indicates that China's import quantity of log is quite sensitive to logs imported from Russia, New Zealand and USA. On the basis of the import quantity index, this paper analyses the changes of China's log imports on the condition of many countries restricting log exports. Considering that the timber legitimacy and forest resources certification are increasingly valued in the world, China's log import will face new challenges in the future.
\end{abstract}

Keywords: log import; demand model; price elasticity; illegal logging; timber legitimacy

\section{Introduction}

In recent years, with economic development and timber industry rapid growth, China has became the world's largest producer of wood products and trading nation. Because of China's forest resources is relatively short, and the nineteen-eighties over-harvesting of forest resources, using the nationwide floods in 1998 as a starting point, the Chinese government has banned the felling natural forest resources. Under this background, the log import market provides an opportunity to China's wood industry development and to solve the contradiction between timber supply and demand. Since 2015, nearly 80\% of China's annual log import is taken by the main origin countries of China's log import (Russian, New Zealand, USA, Papua New Guinea, Malaysia, Gabon), thus China's consumption demand of log severely relies on the international market ${ }^{1}$.

By studying the demand function of China between the main log import countries, this research is expected to identify the structures and trends of the log import countries, and to study the demand problem of China's log import under the circumstances of international combating illegal logging, which is in favor of preventing the trade conflicts with the original countries for the security of China's forestry industry and handling the trade policies of the original countries to restrict log exports, therefore benefiting the sustainable development of China's forest products trade. By analyzing the changes of China's log imports in the context of combating illegal logging, this paper will be able to identify the relationships between China's log import and illegal logging. 


\section{The Quantities and Values of China's Log Import}

Since China's reform and opening up, a rapid growth of exports has always been the long term goal for China's foreign trade, thus accumulated a great number of state's foreign exchange reserves, which guarantee the funds for timber resources imports. After natural forest protection project enacted in 1998, a number of policies have been introduced to encourage the timber raw material imports. These preferential policies to stimulate log imports reduce the dealers' import costs and provide a differentiated policy support under the raw materials imports plan controlled by the national foreign trade ${ }^{2}$.

The price of imported wood materials directly affects the domestic timber market, due to shortage of domestic timber supply capacity, the volumes and values of China's log imports have speeded up the growth in recent years. From 1996 to 2015, China's timber imports increased by 13.99 times, leaped over 40 million $\mathrm{m}^{3}$ mark in 2011. From analysis of the import quantity, China's timber import mainly comes from countries such as Russia, New Zealand, and USA etc ${ }^{3}$. By 2015, the import volume of Russian has reached the peak of 10.61 million $\mathrm{m}^{3}$, accounted for $23.82 \%$ of the total log imports in China. China's log imports volume from New Zealand has increased rapidly to 10.77 million $\mathrm{m}^{3}$ in 2015, accounting for $24.16 \%$ of the total log imports in China, becoming the fastest source of growth in China's timber importer origins. Besides, Papua New Guinea and the United States being the third and the fourth largest source countries of China's log imports respectively. The quantity of Gabon and Myanmar's log exports to China is not dominant, but the value ratio of logs in these sources is quite high, thus still being the important regions for China's log imports ${ }^{4}$. Specific data shows in Table 1.

Table 1: The trade volume share of China's main log import partners from 1996 to 2015

\begin{tabular}{lcc}
\hline Origins & Trade volume & Proportion \\
\hline Russian & $240,367,860$ & $44.68 \%$ \\
New Zealand & $71,831,353$ & $13.35 \%$ \\
Papua New Guinea & $33,445,150$ & $6.22 \%$ \\
USA & $29,614,378$ & $5.51 \%$ \\
Malaysia & $24,699,539$ & $4.59 \%$ \\
Gabon & $14,069,358$ & $2.62 \%$ \\
Myanmar & $12,762,645$ & $2.37 \%$ \\
Other & $111,140,172$ & $20.66 \%$ \\
\hline Total & $537,930,455$ & $100.00 \%$ \\
\hline
\end{tabular}

Data Sources: Annual data from UN COMTRADE DATABASE during 1996 to 2015 


\section{The Model of China's Log Imports Demand and Demonstration}

\subsection{Hypothesis of model}

Considering the differences between domestic timber products and imported like products from other countries, a differentiation model of import demand is adopted to analyze it ${ }^{5}$. This model is derived through the profit maximization function of product importers. Firstly, it is assumed that product importers organize operations following the profit maximization principle under a given production possibility curve, then they follow the cost minimization principle to buy raw materials under the established production quantity.

Suppose that there is a manufacturer of multiple forest products, let $\mathrm{P}=\left[P_{1}, \cdots, P_{m}\right]$ as $\mathrm{m}$ kinds of possible outputs, $\mathrm{q}=\left[q_{1}, \cdots q_{n}\right]$ as $\mathrm{n}$ kinds of input vectors, therefore, the production function can be simply expressed in the form of a vector, as follows:

$$
\mathrm{h}(P, q)=0
$$

Assuming that Eqg.(1) satisfies twice derivable, continuity an homogeneity, calculate the total differential of Eqs.(1), the scale elasticity can be obtained :

$$
\sum_{i=1}^{n} \frac{\partial h}{\partial \log q_{i}}=\sum_{i=1}^{n} \frac{w_{i} q_{i}}{\lambda}=\sum_{i=1}^{n} \frac{c_{i}}{\lambda}
$$

In Eqs.(2), $w_{i}$ represents the price of the log products imported from a country, $c_{i}$ stands for the cost of log products imported from a country, and $\lambda$ is the Lagrange multiplier. Let $\gamma=$ $\lambda / \mathrm{C}, \mathrm{C}$ represents the total costs of imported log products.

The mean of Divisia index can be expressed as:

$$
\theta_{i}=\sum_{r=1}^{m} m_{r} \theta_{i}^{r}=\frac{1}{\lambda} \sum_{r=1}^{m} \frac{\partial\left(w_{i} q_{i}\right)}{\partial \log P_{r}}
$$

$\theta_{i}$ is defined as the marginal cost index of the elements. If this value is greater than zero, it means that when log imports gross increases, the quantity increasing extent of log products imported from i country rises; if this value is less than zero, vice versa.

The demand change of a factor is determined collectively by the change of share, change of output and the change of input prices of the factor, the self and cross demand-price elasticity of factor conditions can be expressed as follows:

$$
\varepsilon_{q, w}=\frac{d\left(\log q_{i}\right)}{d\left(\log w_{i}\right)}=-\frac{\psi\left(\theta_{i j}-\theta_{i} \theta_{j}\right)}{s_{i}}
$$

When $\mathrm{i}=\mathrm{j}$, this elasticity becomes the self price elasticity of factor conditions; When $\mathrm{i} \neq \mathrm{j}$, this elasticity becomes the cross price elasticity of factor conditions. The Divisia index of import quantity can be denoted as:

$$
\varepsilon_{q, Q}=\frac{d\left(\log q_{i}\right)}{d(\log Q)}=\frac{\theta_{i}}{s_{i}}
$$

The denominator $\mathrm{Q}$ in the index stands for the total import volume of log products. The 
numerator $q_{i}$ denotes the quantity of log products imported from i country. It can be seen that The Divisia index of import quantity can reflect the priority of imports. When the total demand of China's log imports increases, the bigger the value is, the greater the increasing extent of log products imported from that country is.

The matrix of log import demand model can be expressed as follows.

$$
s_{i} d\left(\log q_{i}\right)=\theta_{i} d(\log Q)+\sum_{j=1}^{n} \lambda_{i j} d\left(\log w_{j}\right)+\varepsilon_{i}
$$

In Eqs.(6), $\log q_{i}$ is a logarithm to express the quantity of log products imported from i country. $\log w_{j}$ represents the price of log products imported from $\mathrm{j}$ country in a logarithmic way, and $s_{i}$ stands for proportion that the quantity of log products imported from i country takes in China's total log imports. $\log \mathrm{Q}$ is a logarithm to express the total volume of China's log imports; $\theta_{i}$ is the marginal cost factor, denoting the marginal cost share of China's log imports.

Let $\lambda_{i j}=\psi\left(\theta_{i j}-\theta_{i} \theta_{j}\right)$ which refers to price coefficient in this paper. If $\mathrm{i}=\mathrm{j}$, this factor stands for self price coefficient; If $\mathrm{i} \neq \mathrm{j}$, this factor stands for cross price coefficient. The price coefficient reflects the relationship between the price and quantity of imported products. If this value is greater than zero, it indicates a positive correlation between price and quantity of the imported products; if this value is less than zero, it indicates a negative correlation between price and quantity of the imported products.

\subsection{Demonstration of data analysis}

The research data is based on the international trade Commodity name and code HS2002 coordinate system (Harmonized System of Commodity Description and Coding), according to the definition of forest products, chapter directory "log"--4403. The specific data is obtained from UN COMTRADE DATABASE, and the history data is based on HS1996, HS1992 sources ${ }^{6}$.

\subsubsection{Parameter estimates}

This paper utilizes China's annual data of log import and import demand models, estimating China's log demand function based on different sources, and identifies the relationship between different sources of China's log import countries to predict the trend of China's log import. According to the log import data from 1996-2015, in order to save the freedom degree of sample estimates, the sources of China's log import are divided into six in the log import demand model, Russia, New Zealand, Papua New Guinea, the United States, Gabon and Others. In actual calculation and estimation, the import demand equation of others is canceled and the corresponding parameters are calculated by the rule of adding-up ${ }^{7}$. The model parameter estimates and results are listed in table 2.

Table 2 listed the model parameter estimates and results of China's log import. Marginal 
budget shares of these origin countries except Gabon are positive, and pass the significance test of $5 \%{ }^{8}$. This illustrates that every $1 \%$ increase of the import budget from China's log demand manufacturers will lead to the corresponding increases of import budget share in Russia, New Zealand, Papua New Guinea, USA and other countries, respectively by $0.569 \%$, $0.148 \%, 0.047 \%, 0.094 \%$ and $0.151 \%$, while import budget for Gabon's log will decline by $0.016 \%$.

Items of price coefficient show that, the self price coefficients of the United States and Gabon have a significant influence on China's log import demand. To be clear, the impact of New Zealand, Papua New Guinea, the United States and Gabon's self price coefficients are negative, respectively being $-0.131,-0.006,-0.068$ and -0.046 , which indicates that every $1 \%$ increase of average price in New Zealand, Papua New Guinea, USA and Gabon's logs will cause some decrease of China's log import quantity from New Zealand, Papua New Guinea, USA and Gabon, respectively by $0.131 \%, 0.006 \%, 0.068 \%$ and $0.046 \%$. Only the cross price coefficients between New Zealand and USA are negative, indicating a significant complementary relationship between this two countries' log in Chinas log demand market. Other cross-price coefficients between these countries are not significant.

Table 2: China’s log import demand model parameter estimates and results

\begin{tabular}{lccccccc}
\hline \multirow{2}{*}{ Origins } & Marginal & \multicolumn{7}{c}{ Price coefficient } \\
\cline { 3 - 8 } & budget share & Russia & New Zealand & PNG & USA & Gabon & Others \\
\hline \multirow{2}{*}{ Russia } & $0.569^{* * *}$ & 0.326 & 0.048 & -0.156 & 0.197 & -0.151 & -0.113 \\
& $(2.767)$ & $(1.104)$ & $(0.233)$ & $(0.871)$ & $(1.544)$ & $(-0.904)$ & $(-0.427)$ \\
\hline \multirow{2}{*}{ New Zealand } & $0.148^{* *}$ & & -0.131 & 0.369 & $-0.141^{*}$ & 0.013 & 0.016 \\
& $(3.491)$ & & $(-1.121)$ & $(-0.906)$ & $(-1.814)$ & $(1.373)$ & $(0.032)$ \\
\hline \multirow{2}{*}{ PNG } & $0.047^{* *}$ & & & -0.006 & 0.005 & 0.002 & 0.037 \\
& $(2.467)$ & & & $(-0.136)$ & $(0.359)$ & $(0.297)$ & $(0.077)$ \\
\hline \multirow{2}{*}{ USA } & $0.094^{* *}$ & & & & $-0.068^{*}$ & 0.054 & 0.005 \\
& $(1.341)$ & & & & $(-2.154)$ & $(1.31)$ & $(0.136)$ \\
\hline \multirow{2}{*}{ Gabon } & -0.016 & & & & & $-0.046 *$ & 0.046 \\
& $(-1.65)$ & & & & & $(-2.143)$ & $(1.387)$ \\
\hline Others & 0.151 & & & & & 0.014 \\
\hline
\end{tabular}

Note: Inside the brackets are T-test value, and ${ }^{* * *}$ indicating sig. $<0.01,{ }^{* *}$ for sig. $<0.05,{ }^{*}$ for sig. $<0.10$.

\subsubsection{The elasticity comparative analysis}

Index of import quantity, self price elasticity and cross price elasticity are calculated by sample means. The results are show in table 3. 
Table 3: Index of import quantity and price elasticity estimates of China’s log import model

\begin{tabular}{lccccccc}
\hline \multirow{2}{*}{ Origins } & \multirow{2}{*}{$\begin{array}{c}\text { Index of } \\
\text { import quantity }\end{array}$} & \multirow{2}{*}{$\begin{array}{c}\text { Self price } \\
\text { elasticity }\end{array}$} & \multicolumn{5}{c}{ Cross price elasticity } \\
\cline { 6 - 8 } & 1.17 & 0.88 & Russia & New Zealand & PNG & USA & Gabon \\
\hline Russia & 3.08 & -1.35 & -0.04 & $/$ & 2.76 & -6.42 & 0.23 \\
New Zealand & 0.83 & -1.17 & -0.01 & 0.07 & $/$ & 0.17 & 0.09 \\
PNG & 4.26 & -2.64 & -0.12 & 0.41 & 1.53 & $/$ & 1.16 \\
USA & -0.23 & -0.55 & 0.15 & -0.29 & 0.12 & 0.20 & $/$ \\
\hline
\end{tabular}

Table 3 shows that the total budget of China's log import is in rich elasticity to Russia, New Zealand and USA, whose index of import quantity are, respectively, 1.17, 3.08 and 4.26; And that budget lacks of elasticity to Papua New Guinea and Gabon, whose elasticity are 0.83 and 0.23 respectively. Index of import quantity shows that every $1 \%$ increase of China's total budget for log import will lead to some increases of China's log quantity from Russia, New Zealand, Papua New Guinea, and USA, by 1.98\%, 3.08\%, 0.83\% and 4.26\%, respectively, which means that USA's log has the highest comprehensive evaluation in China's timber market, followed by New Zealand, Russia, Papua New Guinea’s logs; while every 1\% increase of China's total budget for log import will cause a $0.23 \%$ reduce of log import quantity from Gabon. Given China's timber demand increases year by year, it can be seen that Gabon gradually reduce timber exports to China. Index of import quantity can reflect the benefit order of China's main log import sources. Namely, when China's total budget for log import increases, the biggest beneficiary is the United States, followed by New Zealand, Russia and Papua New Guinea, meanwhile the benefit of Gabon will decrease.

From the item of self price elasticity, that of New Zealand, Papua New Guinea, USA and Gabon are negative, being $-1.35,-1.17,-2.64$ and -0.55 , respectively. This indicates that logs imported from New Zealand, Papua New Guinea, USA and Gabon are normal goods in China's timber market. Namely, an increase in the price will lead to drops in import quantity, and vice versa. The self price elasticity of Russia is positive, being 0.88 , which shows that logs imported from Russia belongs to luxury goods in China's timber market. Namely, an increase in the price leads to an increase of import quantity instead. Furthermore, the self price of logs imported from New Zealand and USA are in rich elasticity, 1\% of price change will cause $-1.35 \%$ and $-2.64 \%$ of import quantity change, accordingly; The self price of logs imported from Russia, Papua New Guinea and Gabon lacks of elasticity, 1\% of price change will cause $0.88 \%,-1.17 \%$ and $-0.55 \%$ of import quantity change, accordingly. This means that Russia, Papua New Guinea and Gabon's log have price competitive advantages over New Zealand and USA's log in China's timber market.

Table 3 shows that in items of cross price elasticity, only that of Russia between USA, New 
Zealand between Papua New Guinea, and USA between Papua New Guinea and Gabon are greater than 1, which are in rich elasticity; The cross price elasticity of other major sources of $\log$ imports are less than 1, which lacks of elasticity. Among these items, the cross price elasticity of Russia between Papua New Guinea and Gabon, New Zealand between USA and Gabon between New Zealand are negative, which indicates a complementary relation between each other. Furthermore, the impact of price changes of Russian logs on China's log imports from Papua New Guinea and Gabon (3.52 and 3.98, respectively) is greater than that of Papua New Guinea and Gabon's price changes on China’s log imports from Russia (0.01 and 0.15, respectively). This indicates that Russia logs has price advantage over Papua New Guinea and Gabon's logs in China's log imports; The cross price elasticity of New Zealand between Papua New Guinea's is positive, showing a substitution relation between them. Furthermore, the impact of price changes of New Zealand's logs on China's log imports from Papua New Guinea (2.76) is greater than that of Papua New Guinea's price changes on China's log imports from New Zealand (0.07). This illustrates that New Zealand has a price advantage compared with Papua New Guinea in China's log imports; the cross price elasticity of USA between Papua New Guinea is positive, showing a substitution relation between them. Furthermore, the impact of price changes of USA's logs on China's log imports from Papua New Guinea (1.53) is greater than that of Papua New Guinea's price changes on China's log imports from USA (0.17). This indicates that USA has a price advantage compared with Papua New Guinea in China’s log imports.

\section{International Illegal Logging and the Challenge of China's Log Import}

The world timber import demand grew at rate 3.1\% a year on average, while China's log imports during 1996-2015 increased at annual rate of 4.97\% an average. This large number of log imports in China, to a certain degree, has accelerated the trend of the world's forest resources reduces. Therefore, China has been under huge pressure of international opinion, "Chinese timber threat" is a new trade protectionism in the field of China's forest products trade, and has become an important cause of trade friction.

Illegal logging, not only brings damage to forest resources and ecological environment in the forest producer countries, but also causes huge impact to timber importer countries ${ }^{9}$. Illegal timber importers use illegal timber, which importing sources cannot be sustained for a long time, thus the sources of raw materials supply is not stable. According to the trade value share of China's main log import partners from 1996 to 2015, China imported nearly 70\% of logs intensively from the Russian, New Zealand, Papua New Guinea, USA, Malaysia, Gabon, and Myanmar China's log imports rely heavily on the above countries. While most of these countries are in Southeast Asia, Russia and central Africa, where forest certification rate is low and the legitimacy problems of the log exports are sensitive. 
In recent years, the demand of timber legality has raised year by year, and the forest certification requirements have been implemented in the major timber markets all over the world $^{10}$. For instance, the European Union is making the "lacey act" in 2008 stipulates that plant raw materials and related products shall not be from the national park, forest reserves, and officially designated areas. Otherwise, plant raw materials and related products shall not be imported to the United States and the importers will be faced with administrative and criminal punishment ${ }^{11}$.

In the current international trade environment, China will be faced with big challenges in log import trade. After many countries sequentially restricting log exports, China' log import demand has gradually turned to those countries and areas with relatively sufficient forest management ability. Since 2008, China's log imports from New Zealand and the United States have continued to increase rapidly. This development trend has provides a good way of thinking for the sustainable development of forestry industry in China ${ }^{12}$.

\section{Conclusion}

This paper employs the differentiation demand system model, based on China's log imports data from main sources of Russia, New Zealand, Papua New Guinea, USA, Gabon, Malaysia and Myanmar, then calculates the demand function of China's log imports, and finally estimates index of import quantity and price elasticity of China's log imports. Concerning about index of import quantity, the highest index belongs to USA, and this reflects the forest management's ability of USA is sufficient enough to expand domestic timber exports and ensure the legality of the timber in the meantime. The index value of New Zealand takes the second place, which shows his comparatively sufficient forest management ability to control their legal production and export of forest resources effectively. Thus New Zealand is able to promote his market share in China's log market rapidly. China's log import quantity index of Russia is close to unit elasticity, being 1.17 , which reflects Russia's efforts to strengthen his own forest resources management and crack down on illegal logging to improve the legality of the timber exports very vividly. The import quantity index of Gabon is only 0.23, which reflects this central African country's effort to combat illegal logging well. Therefore, China's log import from Gabon showed a steep fall and reduced sharply year by year.

International calls for combating forest illegal logging and tighter regulations are taken seriously in recent years. The world's major log outputs current days, represented by southeast Asia, Russia, Africa, South America and other countries and regions, have adjusted the forest resources management strategy to control the illegal logging strictly, and have made relative policies to restrict log exports, for the sake of protecting domestic forest resources and promoting the development of domestic wood processing industry ${ }^{13}$. The above policies will increase the cost of timber imports in China, and suppress the enthusiasm of timber manufacturer enterprises in China. In the current international trade environment, China will 
be faced with big challenges in log import trade. Under this circumstances, how to look for stable and strong wood supply partners with sufficient forest resources management ability becomes the top priority in China.

\section{References}

1. T. Michinaka, S. Tachibana, J. A. Turner, Econometric Analysis of Radiate Pine Log Trade between New Zealand and East Asian Countries, J. Japan Agricultural Research Quarterly. 45(2011) 327-336.

2. Y. Gao, W. M. Tian, China's soybean import demand analysis, J. Chinese Rural Economy. 5 (2007) 33-40.

3. J. Simeone, Timber export taxes and trade between Russia and China, J. Development of the forestry sector in the Russian Far East. 88 (2012) 585-592.

4. J. J. Sun, X. X. Huo, Demand for Imported Apples in China, J. Agricultural Economics and Management. 2(2014) 59-71.

5. M. A. Ramirez, C. A. Wolf, Source Differentiated Mexican Dairy Import Demand, J. International Food and Agribusiness Management Review. 11 (2008) 35-50.

6. H. Q. Yang, Y. Nie, Original Countries Structure of Chinese Log Import Demand: Based on the Data of 1992- 2006, J. Journal of International Trade,. 2 (2008) 51-56.

7. J. Baek, The Long-run Determinants of U.S. Lumber Imported from Canada Revisited, J. Forest Policy and Economicse,. 14 (2012) 69-73.

8. L. He, X. X. Huo, Import demand model choice and elasticity analysis: take United States apple juice import demand as an example, J. Statistics \& Information Forum. 7 (2011) 38-44.

9. B.D. Cheng, Y. H. Zhang, G. M. Zhao, Analysis on current status and development trend of world forest products trade, J. China Forest Products Industry. 4 (2011) 33-37.

10. M. A. Ramirez, C. A. Wolf, Source Differentiated Mexican Dairy Import Demand, J. International Food and Agribusiness Management Review. 11 (2008) 35-50.

11. J. Buongiorno, J. J. Chou, R. N. Stone, A Monthly Model of the United States Demand for Softwood Lumber Imports, J. Forest Science. 25 (1979) 641-655.

12. J. $L . L u, W . M . L u$, Research on issue of international timber illegal logging and associated trade, J. China Forestry Economy. 3 (1999) 78-90.

13. L. H. Yang, S. H. Yin, Challenges and countermeasures of Chinese forest products trade under new situation, J. Issues of Forestry Economics. 4 (2011) 45-57. 